\title{
Effects of Organic Mineral Dietary Supplementation on Production Performance and Egg Quality of White Layers
}

\begin{tabular}{l} 
DAuthor(s) \\
\hline Fernandes $\mathrm{JIM}^{1}$ \\
Murakami $\mathrm{AE}^{2}$ \\
Sakamoto $\mathrm{MI}^{3}$ \\
Souza $\mathrm{LMG}^{2}$ \\
Malaguido $\mathrm{A}^{4}$ \\
Martins $\mathrm{EN}^{2}$ \\
1 Departamento de Zootecnia - UFPR, \\
Palotina, PR. \\
2 Departamento de Zootecnia - PPZ/UEM. \\
Maringá, PR. \\
3 Departamento de Zootecnia - FZEA/USP. \\
Pirassununga, SP \\
4 Alltech do Brasil. Curitiba, PR.
\end{tabular}

Mail Address

Alice Eiko Murakami

Rua Arthur Thomas 259 apto 1202

87.013-250. Maringá, PR, Brazil.

E-mail: aemurakami@uem.br

\section{Keywords}

Egg quality, organic minerals, productive performance.

\section{ABSTRACT}

This trial aimed at evaluating the effect of organic trace mineral supplementation of commercial layer diets on productive performance and egg quality. One-hundred-ninety-two Hy Line W36 white 69-w-old layers were distributed into a completely randomized design with three treatments, and eight replicates, with eight birds each. Treatments consisted of a basal diet supplemented with inorganic trace minerals (R1), and two others experimental diets containing $0.250 \mathrm{ppm}$ (R2) and $0.500 \mathrm{ppm}$ (R3) of an organic source of zinc, manganese, and selenium. Feed intake ( $\mathrm{g} / \mathrm{bird} /$ day), feed conversion ratio ( $\mathrm{kg} /$ dozen egg and $\mathrm{kg} /$ $\mathrm{kg}$ egg), egg weight (g), egg production (\%), thin and cracked eggshells $(\%)$, specific gravity $(\mathrm{g} / \mathrm{mL})$, Haugh Units, total egg solids (\%), yolk yield, white and shell yields (\%), eggshell thickness, and egg Se content were evaluated Tukey's test analyzed differences among means at 5\% of probability using PROC GLM in SAS (2000). Although not significant as compared to the non-supplemented diet, improvements on relative cracked-plus-thin shells were observed with the use of organic mineral blend. The addition of the organic blend to the diet at $0.250 \mathrm{~kg} / \mathrm{ton}$ resulted in $(p<0.05)$ higher total egg solids. Also, as compared to eggs from control group, fresh and dried yolk yields were higher with the dietary inclusion of the organic mineral blend at 0.250 and $0.500 \mathrm{~kg} / \mathrm{ton}$.

\section{INTRODUCTION}

Trace minerals are essential in poultry diets as they participate in biochemical processes required for normal growth and development. Therefore, there is currently an increasing interest in studying factors that improve absorption and metabolization of these trace elements. Organic sources or metal chelates have been used with the aim of enhancing trace mineral bioavailability by binding minerals to organic molecules, allowing the formation of structures with unique characteristics and high bioavailability (AAFCO, 1997).

These metal complexes may improve egg production and decrease mortality and stress, as well as reduce the excretion of potentially contaminant minerals in environment, as they are absorbed and retained in the poultry body. However, practical results of their use in poultry are still conflicting.

Pimentel et al. (1991) did not observe any differences in relative bioavailability between oxide and organic zinc sources in broilers. Baker et al. (1991) evidenced similar utilization of organic copper and copper sulfate, but higher zinc oxide availability in broilers. On the other hand, Kienholz (1992) showed that feeding zinc chelate to layers submitted to heat stress, associated with low calcium intake, maintained size egg, whereas inorganic zinc supplementation reduced egg size.

Paik (2001) evaluated the utilization of organic zinc, copper, and 
Fernandes JIM, Murakami AE, Sakamoto MI, Souza LMG, Malaguido A, Martins EN
Effects of Organic Mineral Dietary Supplementation on Production Performance and Egg Quality of White Layers manganese, either individually or in combination, and observed improvement in the production performance of birds fed organic copper and the combination of these three metals in an organic complex. However, no performance improvement was observed with the use of either organic zinc or the combination of copper and zinc chelates.

Improvements on the performance and egg quality of brown layers during the second laying cycle were observed by Xavier et al. (2004). These authors verified beneficial effects on these parameters with the use of organic selenium, zinc, and manganese combinations. Conversely, Sechinato et al. (2006) did not find any effects of the supplementation of organic minerals on the performance and egg production of 48- to 60week-old layers as compared to inorganic sources.

As there is an increasing availability of commercial presentations of organic minerals, the use of organic selenium in poultry nutrition should be evaluated due to its function and practical applications.

Selenium is an essential nutrient. Its role in metabolism is mainly related to the synthesis of Seamino acid and Se-protein complexes that act as potent antioxidants. In addition to its antioxidant function, selenium affects egg quality. Wakebe (1999) apud Papas et al. (2005) showed that Se addition to layer diets can mitigate the reduction of Haugh units in stored eggs.

According to the NRC (1994), Se requirement for layers ranges from 0.05 to $0.08 \mathrm{ppm}$, depending on daily feed intake. However, according to Cantor et al. (1997), Se supplementation effects may be different, according to the source used - either in the inorganic (sodium selenite) or organic (selenium cystine and seleniummethionine) forms.

Quantification of Se deposition in the bone has been used to measure the absorption of this trace mineral (Latshaw \& Osman, 1975). According to Surai (2000), Se concentration in the egg increases as a function of dietary supplementation.

According to Payane et al. (2005), experimental studies comparing inorganic and organic Se sources showed that both Se presentations increased Se egg content, but the organic form was more efficient (Swanson, 1987; Davis et al., 1996; Cantor et al., 2000). Surai $(2002 a, b)$ attributed the difference to the absorption mechanism of each source. Inorganic Se is passively absorbed, while Se-methionine is submitted to active absorption, consistent with the absorption process of methionine.

Low-selenium diets were associated with high incidence of human cancer (Allan et al., 1999); therefore, Se enrichment may add value to eggs. Over and above the high nutritional value of eggs, Seenriched eggs may contribute with $50 \%$ of daily Se requirement of humans (Nadezda et al., 2006).

The present experiment aimed at evaluating the effects on performance, egg quality, and Se deposition in eggs obtained from white layers fed diets supplemented with an organic mineral mixture.

\section{Material and Methods}

The experiment was performed at poultry facility of Iguatemi Experimental Farm (FEI) of Maringá State University (UEM). One hundred and ninety two 67-w old HyLine W36 layers were housed in 24 metal battery cages, $30 \mathrm{~cm}$ wide $\times 45 \mathrm{~cm}$ deep, divided into four pens of two birds each, housing eight birds per cage.

A complete randomized experimental design, with three treatments and eight replicates of eight birds each, was applied. A period of 14 days was used to adapt the birds to the experimental diets, which was followed by an experimental period of 16 weeks or four 28-d laying cycles.

Treatments consisted of a basal diet, supplemented with inorganic minerals (R1), and two other experimental feeds containing 0.250 ppm (R2) or 0.500 ppm (R3) of an organic zinc, manganese, and selenium mixture. Corn-soybean experimental diets (Table 1) were formulated to meet 67-to-83-w-old white layers nutritional requirements, as proposed by Hy-Line Breeder Company (Management Guides Hy-Line W36, 2000).

Hens were submitted to artificial lighting, starting at sunset, with a program of $17 \mathrm{~h}$ of light per day. Feed and water were supplied ad libitum. Average temperatures (maximum and minimum) were recorded during the entire experimental period.

Feed intake and feed conversion ratio ( $\mathrm{kg}$ feed/ dozen eggs and $\mathrm{kg}$ feed $/ \mathrm{kg}$ egg) data were recorded every 28 days. Egg production and number of thin plus cracked eggshells were daily recorded. At the end of each laying period, total egg production and \% egg production were calculated for each experimental unit.

At the end of every 28-day- laying cycle and for three consecutive days, internal and external egg qualities were analyzed. Intact eggs from each replication were individually identified and weighed on a precision digital scale $(0.01 \mathrm{~g}$ precision), and further subjected to a specific gravity test by flotation method in saline solution. Six solutions (water and salt) with 
Fernandes JIM, Murakami AE, Sakamoto MI, Souza LMG, Malaguido A, Martins EN
Effects of Organic Mineral Dietary Supplementation on Production Performance and Egg Quality of White Layers density ranging from 1.070 to 1.090 with increments of 0.004 units were used. Gravities were checked on by a petroleum densimeter.

\begin{tabular}{|c|c|c|c|}
\hline \multirow{2}{*}{ Ingredients } & \multicolumn{3}{|c|}{ Experimental diets } \\
\hline & R1 & R2 & R3 \\
\hline \multicolumn{4}{|l|}{ Composition, \% } \\
\hline Corn & 61.38 & 61.32 & 61.27 \\
\hline Soybean meal & 23.42 & 23.43 & 23.44 \\
\hline Limestone & 10.54 & 10.54 & 10.54 \\
\hline Dicalcium phosphate & 1.44 & 1.44 & 1.44 \\
\hline Soybean oil & 2.45 & 2.47 & 2.49 \\
\hline Salt & 0.34 & 0.34 & 0.34 \\
\hline $\mathrm{DL}-$ Met & 0.145 & 0.145 & 0.145 \\
\hline Vitamin-mineral premix ${ }^{1}$ & 0.250 & 0.250 & 0.250 \\
\hline Zinc bacitracin, $15 \%$ & 0.030 & 0.030 & 0.030 \\
\hline Organic trace mineral blend ${ }^{2}$ & 0.000 & 0.025 & 0.050 \\
\hline \multicolumn{4}{|l|}{ Calculated values } \\
\hline Crude protein (\%) & 16.00 & 16.00 & 16.00 \\
\hline ME (kcal/kg) & 2.850 & 2.850 & 2.850 \\
\hline $\mathrm{Ca}(\%)$ & 4.50 & 4.50 & 4.50 \\
\hline P, available (\%) & 0.36 & 0.36 & 0.36 \\
\hline Met+Cys, digestible (\%) & 0.60 & 0.60 & 0.60 \\
\hline Met, disgestible (\%) & 0.37 & 0.37 & 0.37 \\
\hline Lys, digestible (\%) & 0.72 & 0.72 & 0.72 \\
\hline Arg, digestible (\%) & 0.96 & 0.96 & 0.96 \\
\hline $\mathrm{Na}(\%)$ & 0.17 & 0.17 & 0.17 \\
\hline $\mathrm{Cl}(\%)$ & 0.23 & 0.23 & 0.23 \\
\hline K (\%) & 0.61 & 0.61 & 0.61 \\
\hline \multicolumn{4}{|c|}{ 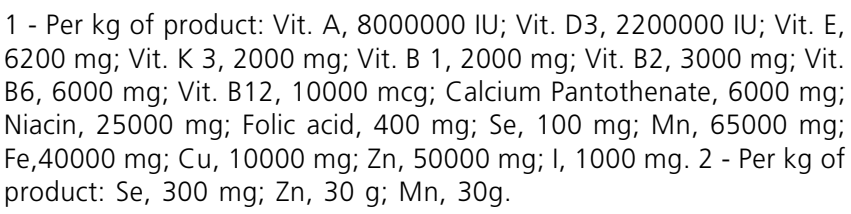 } \\
\hline
\end{tabular}

A sample of three eggs per replication was used to determine yolk weight, white weight, eggshell yield (\% related to egg weight), yolk and albumen solids yields (\% related to albumen and yolk weights, respectively), and eggshell thickness $(\mathrm{mm})$. Total solids were analyzed in the remaining eggs.

For evaluation of total egg, yolk, and white solids, three homogenized eggs (yolk plus white), three yolks and three albumens were individually weighed and dried at $55^{\circ} \mathrm{C}$ in a forced-air convection oven for at least 72 h. After approximately $2 \mathrm{~h}$ at environmental temperature, samples were weighed, and their yields calculated relative to respective initial weights. Samples of homogenized eggs were also used for selenium measurement, which was determined in blue flame (air-acetylene) atomic absorption apparatus (recorded at $196.0 \mathrm{~nm}$ ) attached to a hydrate generator.

Washed shells were left for $72 \mathrm{~h}$ at environmental temperature, dried, individually weighed, and their relative weights calculated as function of egg weight.
Shells from three eggs per replicate were taken at the end of each production cycle to measure thickness in three equatorial regions of each shell using a manual micrometer (Mitutoyo ${ }^{\circledR}$ ).

A fourth day of egg collection was used for quality evaluation of stored eggs by albumen height measurements. The eight replicates were pooled in four groups per treatment in order to achieve a sufficient number of eggs to be evaluated (maximum 16 eggs/ group and 64 eggs/treatment). During the day of collection and on days 3, 6, 9, and 12th days, all eggs per replicate were weighed, cracked on a flat glass surface, and white height was measured between external border and the yolk with the aid of a manual micrometer. Albumen height was correlated to egg weight, according to the following formula introduced by Brant et al. (1951).

\section{Haugh Units $=100 \log \left(H+5.57-1.7 W^{0,37}\right)$}

Where:

$\mathrm{H}=$ albumen height (mm); $\mathrm{W}=$ egg weight $(\mathrm{g})$

Data were submitted to ANOVA, and when necessary means were discriminated by Tukey's test at $5 \%$ of probability with the use of PROC GLM of SAS software (SAS, 2000). Also, analyses of regression for Haugh units and selenium concentration in eggs as function of storage time and production cycles, respectively, were processed.

\section{RESULTS E DISCUSSION}

\section{Mean Body Weight of the Birds}

Initial (69-w-old) and final (85-w-old) weights of laying hens were uniform and independent of treatments (Table 2).

\section{Egg Production and Egg quality}

Layer performance and egg quality results are presented in Table 3. Eggs from hens fed the control diet or that supplemented with 500 ppm of organic trace minerals were significantly heavier $(p<0.05)$. However, no difference ( $p>0.05)$ was observed among employed levels of organic trace minerals.

Although the significant differences in egg weight observed among treatments, egg masses proved to be similar $(p>0.05)$. This result occurred because no difference was observed in egg production percentage, in agreement both with Cantor et al. (2000) and Patton (2000) 
Fernandes JIM, Murakami AE, Sakamoto MI, Souza LMG, Malaguido A, Martins EN
Effects of Organic Mineral Dietary Supplementation on Production Performance and Egg Quality of White Layers
Feed intake and feed conversion ratio were not influenced by any supplementation level of organic trace minerals as compared to birds fed exclusively inorganic sources.

\begin{tabular}{|c|c|c|}
\hline Treatment & Initial body weight, g & Final body weight, $g$ \\
\hline Control & 1749 & 1847 \\
\hline 250 ppm & 1773 & 1849 \\
\hline 500 ppm & 1778 & 1875 \\
\hline
\end{tabular}

\begin{tabular}{|c|c|c|c|c|c|}
\hline \multirow[b]{2}{*}{ Parameter } & \multicolumn{3}{|c|}{ Organic mineral mix (ppm) } & \multirow{2}{*}{$\begin{array}{l}\text { CV } \\
(\%)\end{array}$} & \multirow[t]{2}{*}{$p<0.05$} \\
\hline & Control & 250 & 500 & & \\
\hline \multicolumn{6}{|c|}{ Productive performance } \\
\hline Egg production (\%) & 76.05 & 75.74 & 74.90 & 5.63 & ns \\
\hline Feed intake (g/bird/d) & 103.15 & 102.16 & 103.99 & 3.68 & ns \\
\hline Feed conversion ( $\mathrm{kg} / \mathrm{doz}$ ) & 1.631 & 1.623 & 1.669 & 5.86 & ns \\
\hline Feed conversion $(\mathrm{kg} / \mathrm{kg})$ & 2.001 & 2.028 & 2.070 & 5.72 & ns \\
\hline Egg weight $(g)$ & $67.92^{\mathrm{a}}$ & $66.71^{\mathrm{b}}$ & $67.23 a b$ & 2.80 & 0.039 \\
\hline Egg mass $(\mathrm{g})$ & 51.63 & 50.47 & 50.37 & 5.40 & ns \\
\hline \multicolumn{6}{|l|}{ Egg quality } \\
\hline Cracked + thin shell eggs & is (\%)1.67 & a $1.20^{b}$ & $1.43^{b}$ & 19.2 & 0.040 \\
\hline Eggshell thickness (mm) & 0.303 & 0.302 & 0.300 & 2.36 & ns \\
\hline Specific gravity (g/ml) & 1.076 & 1.075 & 1.075 & 0.14 & ns \\
\hline Eggshell (\%) & $8.24^{\mathrm{a}}$ & $7.97^{b}$ & $8.03^{a b}$ & 4.29 & 0.007 \\
\hline Haugh Unit & 90.78 & 89.28 & 89.59 & 7.43 & ns \\
\hline Total solids (\%) & $25.62 b$ & b $26.08^{a}$ & $25.88 a b$ & 2.76 & 0.038 \\
\hline Yolk (\%) & $28.46^{b}$ & $28.88^{a}$ & $28.99^{\text {a }}$ & 4.00 & 0.003 \\
\hline Yolk, solids (\%) & $16.36^{b}$ & $16.62^{a}$ & $16.67 \mathrm{a}$ & 4.75 & 0.018 \\
\hline Albumen (\%) & 57.91 & 57.49 & 57.88 & 3.65 & ns \\
\hline Albumen, solids (\%) & 7.14 & 7.19 & 7.18 & 5.82 & ns \\
\hline
\end{tabular}

$\mathrm{CV}=$ coefficient of variation; $\mathrm{ns}=$ not significant. Values with different letters in row line are statistically different by Tukey's test $(P<0,05)$.

Sechinato et al. (2006) also did not detect any effects of zinc, manganese, copper, iron, or selenium supplementation, alone or combined, either in organic or inorganic form, on egg production or egg quality of 48-to-60-w-old layers.

Payane et al. (2005) reported that responses to mineral supplementation depend on the mineral concentration in basal diet. There is a broad consensus in formulation of mineral or vitamin premixes that is necessary to supplement microelements with a wide safety margin, superior to the required levels (Dale \& Strong, 1998). Therefore, the control diet alone may supply all trace-mineral requirements, becoming impossible to detect any additional benefits, independent of the presentation of minerals, either in organic or inorganic. Different results reported in technical literature on commercial products may be attributed to the specific chelating procedures employed, resulting in products with different bioavailabilities, stabilities, and metabolization.
Eggshell yields were similar to the described patterns found for egg weight. Higher eggshell yields were recorded in layers fed control diet and 500 ppm of the organic trace mineral blend. Again, there were no differences among levels of organic trace mineral supplementation on eggshell quality.

Siske et al. (2000) reported increasing eggshell thickness when organic manganese, zinc, and selenium replaced $50 \%$ of inorganic presentations of these trace minerals.

Trace minerals may affect eggshell quality due to their catalytic properties as constituents of key enzymes involved in the processes of membrane and eggshell synthesis or by direct interaction with calcium crystals during eggshell formation.

Notwithstanding the observed positive effects of the organic trace mineral supplementation on the percentage of cracked eggs, eggshell thickness, and specific gravity, no other differences among treatments were detected (Table 3). Dale \& Strong (1998) also did not report significant improvement of egg quality by supplementing either organic or inorganic trace mineral blends. However, when the supplementation of organic trace minerals was replaced by inorganic sources, significantly lower egg specific gravity was obtained.

In addition, Mabe et al. (2003) did not find any changes in eggshell yield with the use of organic zinc or organic manganese. Other experiments demonstrated the absence of effect of the supplementation of levels above the requirements of these trace minerals on the eggshell quality (Karunajeewa \& Tham, 1987; Ochrimento et al., 1992; Faria et al., 1999).

No differences $(p<0.05)$ in Haugh Units were recorded at each end of laying period, neither on those obtained during storage periods (days 3, 6, 9, and 12; Tables 3 and 4). However, in all evaluated laying cycles (1 to 4), a quadratic trend to increase albumen height as a function of storage time (days $0,3,6,9$, and 12) was observed, as shown in Figure $2\left(Y_{1}=97.0264\right.$ $6.89886 X+0.285992 X^{2} ; r^{2}=0.95, Y_{2}=93.6667-$ $8.05983 X+0.322365 X^{2} ; r^{2}=0.93 ; Y_{3}=91.1863-$ $6.67049 X+0.87527 X 2 ; r^{2}=0.91 ;$ and $Y_{4}=96.2475-$ $\left.8.27555 X+0.279126 X^{2} ; r^{2}=0.96\right)$.

Internal egg quality is usually evaluated by measurements of either white height or Haugh Units, which is a function of the former characteristic. Both parameters are related to egg storage conditions in supermarkets shelves. Although egg storage is an essential trait for retailers, some changes in egg internal characteristics must be expected, e.g., water and 
Fernandes JIM, Murakami AE, Sakamoto MI, Souza LMG, Malaguido A, Martins EN
Effects of Organic Mineral Dietary Supplementation on Production Performance and Egg Quality of White Layers carbon dioxide losses, and $\mathrm{pH}$ increase (Decuypere et al., 2001). Albumen quality is indirectly related to amount of carbon dioxide lost since the moment of lay (Wakebe, 1998). Carbon dioxide diffusion increases $\mathrm{pH}$ (Williams, 1992; Brake et al., 1997; Silversides and Scott, 2001), resulting in the dissociation of two egg white proteins that are responsible for its viscosity, lisozyme and ovomucin (Williams, 1992).

\begin{tabular}{|c|c|c|c|c|c|}
\hline \multirow[b]{2}{*}{ Days } & \multicolumn{3}{|c|}{ Organic tracemineral blend (ppm) } & \multirow{2}{*}{$\begin{array}{l}\text { CV } \\
\%\end{array}$} & \multirow[t]{2}{*}{$p<0.05$} \\
\hline & Control & 250 & 500 & & \\
\hline 1 & 88.87 & 88.84 & 90.33 & 8.83 & ns \\
\hline 3 & 69.80 & 68.27 & 72.63 & 11.27 & ns \\
\hline 6 & 61.58 & 61.34 & 62.47 & 5.86 & ns \\
\hline 9 & 47.99 & 50.46 & 49.37 & 6.98 & ns \\
\hline 12 & 44.72 & 40.76 & 42.72 & 10.14 & ns \\
\hline
\end{tabular}

$\mathrm{CV}=$ coefficient of variation; $\mathrm{ns}=$ non significant.

\begin{tabular}{|c|c|c|c|c|c|}
\hline & \multicolumn{3}{|c|}{ Organic tracemineral blend (ppm) } & \multirow{2}{*}{$\begin{array}{l}\text { CV } \\
\%\end{array}$} & \multirow[t]{2}{*}{$p<0.05$} \\
\hline & Control & 250 & 500 & & \\
\hline Se $(\mathrm{mg} / \mathrm{kg})$ & 1.029 & 0.973 & 1.376 & 51.31 & ns \\
\hline
\end{tabular}

$\mathrm{CV}=$ coefficient of variation; $\mathrm{ns}=$ not significant.

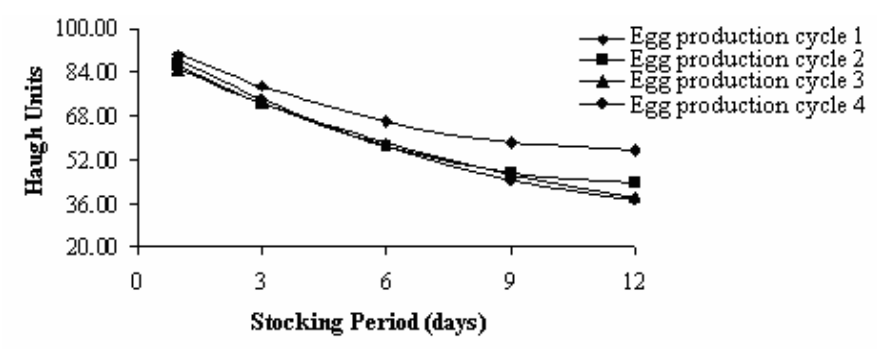

Figure 1 - Haugh units of egg as function of storage period.

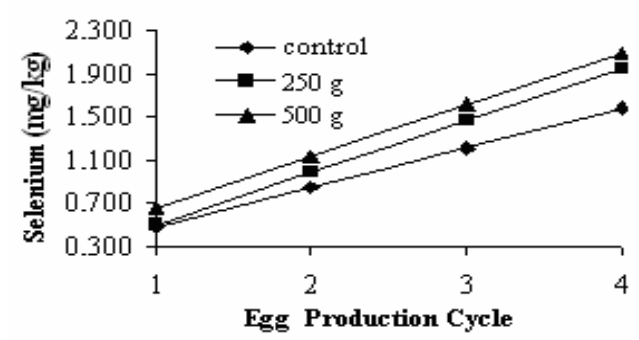

Figure $\mathbf{2}$ - Se deposition in eggs of commercial layers fed the organic trace mineral blend.

Age and laying stage affect eggshell structure, and consequently rate of diffusion through shell pores. Therefore, probably due to the age of our experimental layers (67 to 83 weeks of age), the supplementation of trace minerals even above requirements did not efficiently prevent these physiologic alterations.
Layer fed the diets supplemented with organic trace minerals presented $(p<0.05)$ higher yolk yield relative to the control treatment. On the other hand, the commercial organic trace mineral blend added to diet at $250 \mathrm{ppm}$ increased the level of yolk solids as compared to the diets supplemented with inorganic trace minerals. Se from the commercial product used in this trial is bound to methionine, and according to Combs \& Combs (1986) this is the form which is actively absorbed and directly incorporated into the egg protein, justifying Se increases in yolk and on total egg solids obtained in the layers fed this trace mineral source.

Experimental treatments did not influence egg Se content ( $p>0.05)$. However, a positive and linear Se increase as function of egg production cycle was observed for all treatments $\left(Y_{R 11}=0.108750+\right.$ $0.368125 X ; r^{2}=0.92 ; Y_{R 2}=0.160003+0.482675 X ; r^{2}=$ 0.95 and $\left.Y_{R 3}=0.76250+0.479700 X ; r^{2}=0.90\right)$, as observed in Figure 3. According to Pappas et al. (2005), Se deposition efficiency increases as layers age, and increases when the diet is over supplemented.

Egg Se deposition depends on dietary mineral content and on the presentation of dietary Se. Organic Se is more efficiently deposited in eggs. (Cantor et al., 1997; Paton \& Cantor, 2000; Surai \& Dvorska, 2001). Dobrzaski et al. (2003) found superior Se concentration (10.47\% higher) in eggs of layers fed enriched yeast containing Se-methionine as compared to groups supplemented with sodium selenite.

Payne et al. (2005) also reported higher Se content in eggs of layers fed Se-methionine. This increase was almost three-fold higher as compared to nonsupplemented diet tested for 28 days. Cantor \& Scott (1974) considered this Se increase beneficial in fertilized eggs since this mineral is naturally transferred from the yolk to the embryo.

\section{CONCLUSION}

Selenium supplementation improved yolk yield and its total solid contents, and the deposition of selenium increased with the age of white layers.

\section{REFERENCES}

Allan CB, Lacourciere GM, Stadtman TC. Responsiveness of selenoproteins to dietary selenium. Annual Review of Nutrition 1999; 19:1-16.

American Association Feed Control Officials - AAFCO. Atlanta; 1997. 


\section{Fernandes JIM, Murakami AE, Sakamoto MI, Souza LMG, Malaguido A, Martins EN}

Brak J, Walsh TJ, Benton Jr. CE, Petitte JN, Meijerhof R, Penalva G. Egg handling and storage. Poultry Science 1997; 76:144-151.

Brant AW, Otte AW, Norris KH. Recommended standards for scoring and measuring opened egg quality. Food Technology $1951 ; 5: 356-361$.

Cantor AH, Scott ML. The effect of selenium in the hen's diet on egg production, hatchability, performance of progeny and selenium concentration in eggs. Poultry Science 1974; 53:1870-1880.

Cantor AH, Straw ML, Ford MJ, Pescatore AJ, Dunlap MK. Effect of feeding organic selenium in diets of laying hens on egg selenium content. In: Sim JS, Nakai S, Guenter W, editor. Egg Nutrition and Biotechnology. New York: CABI Publishing; 2000. p.473

Cntor AH, Pescatore J, Straw ML, Ford MJ, Dunlap MK. Tissue selenium concentrations of broilers fed diets suplemented with selenized yeast and sodium selenite. Poultry Science 1997; 76(1):58.

Combs Jr GF, Combs SB. The role of selenium in nutrition. Orlando,FL: Academic Press; 1986.

Dale N, Stong CF. Inability to demonstrate an effect of eggshell 49 on shell quality in older laying hens. Journal of Applied Poultry Research 1998; 7:219-224.

Davis RH, Fear J, Winton AC. Interactions between dietary selenium, copper, and sodium nitroprusside, a source of cyanide in growing chicks and laying hens. British Poultry Science 1996; 37:87-94.

Decuypere E, Tona K, Bruggeman V, Bamelis F. The day-old chick: A crucial hinge between breeders and broilers. World's Poultry Science Journal 2001; 57:127-139.

Dobrzaski Z, Jamroz D, Górecka H, Opaliskis S. Bioavailability of selenium and zinc supplied to the feed for laying hens in organic and inorganic form. Animal Husbandry 2002; 692(2). Available from: www.ejpau.media.pl.

Faria DE, Junqueira OM, Sakomura NK, Santana AE. Effect of different levels of manganese and phosphorus on the performance and eggshell quality of laying hens. Brazilian Journal Animal Science 1999; 28:105-112.

Karunajeewa $\mathrm{H}$, Tham SH.The effect of rice pollar and manganese levels in diet on egg weight, shell quality and performance of crossbred layers. Journal Science Food Agricultural 1987; 41:141152.

Kienholz EW. Zinc methionine for stressed laying hens. Poultry Science 1992; 71:829-832.

Latshaw JD, Osman M. Distribution of selenium in egg white and yolk after feeding normal synthetic selenium compounds. Poultry Science 1975; 54:1244-1252.

Mabel I, Rapp C, Bain MM, Nys Y. Supplementation of a cornsoybean meal diet with manganese, copper, and zinc from organic or inorganic sources improves eggshell quality in aged laying hens. Poultry Science 2003; 82:1903-1913.
Nadezda A, Golubkina A, Tigran T, Papazyan B. Selenium distribution in eggs of avian species. Comparative Biochemistry and Physiology 2006; 145:384-388.

Ochrimento C, Lemser A, Richtter G, Krause U, Bonsak H. Effect of manganese content in laying hen feed with different $\mathrm{Ca}$ and mineral level on the eggshell quality and bone mineralization of hens. Archiv Fur Tierenaehrung 1992; 42:25-35.

Paik I. Application of chelated minerals in animal production. AsianAustralasian Journal of Animal Sciences 2001; 14:191-198.

Pappas AC, Acamovic T, Sparks NHC, Surai PF, McDevitt RM. Effects of supplementing broiler breeder diets with organic selenium and polyunsaturated fatty acids on egg quality during storage. Poultry Science 2005; 84:865-874.

Paton ND, Cantor AJ. Effect of dietary selenium source and storage on internal quality and shell strength of eggs. Poultry Science 2000; 79 (Suppl. 1):116.

Payne RL, LavergneTK, Southern LL. Effect of inorganic versus organic selenium on hen production and egg selenium concentration. Poultry Science 2005; 84:232-237

Pimentel JL, Cook ME, Greger JL. Bioavailability of zinc-methionine for chicks. Poultry Science 1991; 70:1637-1639.

SAS Institute. SAS/STAT user's guide: statistics. elease 6.08. Cary, NC; 1990.

Sechinato AS, Albuquerque R, Nakada S. Efeito da suplementação dietética com micro minerais orgânicos na produção de galinhas poedeiras. Brazilian Journal Veterinary Research Animal Science 2006; 43:159-166.

Silversides FG, Scott TA. Effect of storage and layer age on quality of eggs from two lines of hens. Poultry Science 2001; 80:12401245.

Siske V, Zeman L, Klecker D. The egg shell: A case study in improving quality by altering mineral metabolism - naturally.In: Lyions TP, Jacques KA, editor. Biotechnology in the feed industry. Proceedings of Alltech's 16th Annual Symposium. T. P. Nottingham, UK: Nottingham University Press; 2000. p.327

Sura PF. Effect of selenium and vitamin E content of the maternal diet on the antioxidant system of the yolk and the developing chick. British Poultry Science 2000; 41:235-243.

Surai PF, Dvorska JE. Is organic selenium better than inorganic sources. Feed Mix 2001; 9:8-10.

Surai PF. Selenium in poultry nutrition 1. Antioxidant properties, deficiency and toxicity. World's Poultry Science Journal 2002a; 58:333-347.

Surai PF. Selenium in poultry nutrition 2. Reproduction, egg and meat quality and practical applications. World's Poultry Science Journal 2002b; 58:431-450.

Swanson CA. Comparative utilization of selenite, selenomethionine, 
Fernandes JIM, Murakami AE,

Sakamoto MI, Souza LMG,

and selenized yeast by the laying hen. Nutrition Research 1987;

7:529-537.

Williams KC. Some factors affecting albumen quality with particular reference to Haugh unit score. World's Poultry Science Journal 1992; 48:5-16.

Xavier GB, Rutz F, Dionello NJL, Arruda JS, Pan EA.Performance of layers fed diets containing organic selenium, zinc and manganese, during a second cycle of production. Proceedings of the Annual Symposium on Biotechnology in the feed industry,20th; 2004; Lexington. p.19. 
